\title{
Efficacy of Peginterferon alfa-2b in Nucleoside Analogue Experienced Patients with Negative HBeAg and Low HBsAg: A Non-Randomized Clinical Trial
}

\author{
Jun Chen · Min Qi · Xue-Gong Fan · Xing-Wang Hu • \\ Cheng-Jin Liao · Li-Yuan Long · Xiao-Ting Zhao • Min Tan • \\ Hai-Fu Li · Ruo-Chan Chen · Ze-Bing Huang · Yan Huang (D)
}

Received: April 7, 2021 / Accepted: June 30, 2021 / Published online: July 25, 2021

(c) The Author(s) 2021

\section{ABSTRACT}

Introduction: Hepatitis B surface antigen (HBsAg) clearance is the treatment goal for hepatitis $\mathrm{B}$ e antigen (HBeAg)-negative patients with chronic hepatitis B (CHB). However, its rate is extremely low with nucleoside (acid) analogues (NAs) monotherapy. Peginterferon could enhance HBsAg clearance. This study aimed to evaluate the efficacy of peginterferon alfa-2b (PegIFN $\alpha-2 b)$ in NAs-experienced patients with $\mathrm{CHB}$ with negative $\mathrm{HBeAg}$ and low HBsAg level.

Methods: HBeAg-negative patients with $\mathrm{CHB}$ who had received NAs therapy over 24 weeks with $\mathrm{HBsAg}<1500 \mathrm{IU} / \mathrm{mL}$ and $\mathrm{HBV}$ DNA $<100 \mathrm{IU} / \mathrm{mL}$ were enrolled. Patients received either PegIFN $\alpha$-2b add-on therapy $(n=108)$ or continuous NAs monotherapy

J. Chen · M. Qi · X.-G. Fan · X.-W. Hu · C.-J. Liao ·

L.-Y. Long - X.-T. Zhao - M. Tan - H.-F. Li ·

R.-C. Chen · Z.-B. Huang $(\varangle) \cdot$ Y. Huang $(\varangle)$

Department of Infectious Diseases, Xiangya

Hospital, Central South University, Xiangya Road

87, Kaifu District, Changsha 410008, China

e-mail: 36165934@qq.com

Y. Huang

e-mail: drhyan@126.com

J. Chen · X.-G. Fan · X.-W. Hu · R.-C. Chen .

Z.-B. Huang · Y. Huang

Key Laboratory of Viral Hepatitis, Hunan, China $(n=75)$. The primary endpoint was HBsAg clearance rate at week 48 .

Results: At week 48, serum HBV DNA was undetectable among all PegIFN $\alpha-2 b$ add-on therapy patients. Almost all patients maintained HBV DNA suppression in the PegIFN $\alpha-2 b$ add-on group $(100 \%, 108 / 108)$ and NAs monotherapy group $(97.33 \%, 73 / 75)$. Only patients with PegIFN $\alpha-2 b$ add-on therapy achieved HBsAg clearance $(50.93 \%, 55 / 108)$ and HBsAg seroconversion (48.15\%, 52/108) at week 48. Patients with baseline HBsAg $<100 \mathrm{IU} / \mathrm{mL}$ achieved the highest HBsAg clearance rate and HBsAg seroconversion rate at week $48(60.87 \%, 28 / 46$ and 58.70\%, $27 / 46$ respectively). HBsAg clearance and HBsAg seroconversion at week 72 had no significant difference with continuing or discontinuing PegIFN $\alpha$-2b therapy after 48 weeks of treatment. PegIFN $\alpha$-2b add-on therapy was well tolerated.

Conclusions: PegIFN $\alpha-2 b$ add-on therapy increases HBsAg clearance rate and seroconversion rate for HBeAg-negative patients with $\mathrm{CHB}$, particularly for those with lower HBsAg level. It would be unnecessary to prolong PegIFN $\alpha-2 b$ duration after 48 weeks of PegIFN $\alpha-2 b$ treatment.

Keywords: Add-on therapy; Chronic hepatitis B; PegIFNa-2b; Nucleoside (acid) analogues 


\section{Key Summary Points}

Why carry out this study?

HBsAg clearance rate is extremely low with nucleoside (acid) analogues (NAs) monotherapy and most patients with CHB need lifelong medication.

The efficacy and optimization of PegIFN $\alpha$ $2 \mathrm{~b}$ add-on therapy for HBeAg-negative patients with $\mathrm{CHB}$ were analyzed in this study.

\section{What was learned from the study?}

PegIFN $\alpha$ - $2 b$ add-on therapy could enhance HBsAg clearance for HBeAg-negative patients with CHB.

Low HBsAg level is a potential predictor of HBsAg clearance by PegIFN $\alpha-2 b$ add-on therapy.

Prolonging PegIFN treatment duration after 48 weeks of PegIFN treatment may not improve the HBsAg clearance.

\section{INTRODUCTION}

Hepatitis B virus (HBV, a hepatotropic virus) can establish a persistent and chronic infection in humans through immune anergy. Currently, about 2 billion people worldwide suffer from $\mathrm{HBV}$ infection, and $3.5 \%$ of the global population (about 257 million individuals) is chronically infected $[1,2]$. Chronic HBV infection is a major public health problem, leading to cirrhosis, liver failure, or hepatocellular carcinoma [3]. Active HBV infection includes hepatitis B e antigen (HBeAg)-positive and HBeAg-negative patients with chronic hepatitis B (CHB). Most HBeAg-negative patients with $\mathrm{CHB}$ have a long course, low spontaneous hepatitis B surface antigen (HBsAg) clearance rate, and low sustained response rate [4-6].

HBsAg clearance is the drug withdrawal indication and the goal of HBeAg-negative

patients with $\mathrm{CHB}$ treatment [7]. However, HBsAg clearance rate is very low after long-term NAs therapy in this population and most of them need lifelong medication [8, 9]. Although nucleoside (acid) analogues (NAs) can suppress viral replication, reactivation is common when treatment is discontinued. For HBeAg-positive patients who achieved HBeAg seroconversion by NAs treatment, virological relapse was up to $71 \%$ within 1 year post NAs discontinuation. In addition, 90\% of HBeAg-negative patients who maintained virological suppression on NAs therapy had a risk of relapse after consolidation therapy for at least a year or decreases [10-14]. Moreover, HBeAg-negative patients with $\mathrm{CHB}$ would suffer virological recurrence, liver function deterioration, severe hepatitis, and high incidence of liver cancer if they had drug withdrawal without obtaining HBsAg clearance $[6,15,16]$. Therefore, new treatment strategies are required to increase $\mathrm{HBsAg}$ clearance rate in HBeAg-negative patients with CHB.

Interferon alfa was the first antiviral drug for CHB treatment. Studies have reported that adding or switching to peginterferon could increase HBsAg clearance rate from $8.5 \%$ to $37.4 \%$ in NAs-treated patients with $\mathrm{CHB}$ [17-20]. The OSST trial and New Switch Study showed that patients with low HBsAg $(<1500 \mathrm{IU} / \mathrm{mL})$ at baseline were more likely to achieve HBsAg clearance compared to those with HBsAg $>1500 \mathrm{IU} / \mathrm{mL}[19,21]$. Beyond previous studies, this study aimed to evaluate the efficacy and safety of peginterferon alfa- $2 b$ (PegIFNa-2b) treatment for HBeAg-negative patients with $\mathrm{CHB}$ who achieved HBsAg $<1500 \mathrm{IU} / \mathrm{mL}$ and HBV DNA $<100 \mathrm{IU} /$ mL by NAs treatment.

\section{METHODS}

\section{Patients}

NAs-treated patients with $\mathrm{CHB}$ in this study were enrolled from outpatient departments of Xiangya Hospital, Central South University during April 2018-October 2019. Patients paid for the drug by themselves in this real-world study and all enrolled patients chose to receive 
PegIFN $\alpha-2 b$ treatment voluntarily with full knowledge and signed an informed consent. This study was in compliance with the Declaration of Helsinki and was approved by Xiangya Hospital Ethics Committee, Central South University.

Inclusion criteria:

1. Patients with $\mathrm{CHB}$ diagnosed according to the Guidelines for the Prevention and Treatment of Chronic Hepatitis B (2019 Edition) in China [22].

2. NAs therapy $\geq 24$ weeks and no interferon therapy within 6 months.

3. HBeAg-negative patients with HBsAg level $<1500 \mathrm{IU} / \mathrm{mL}$ and HBV DNA level $<100 \mathrm{IU} / \mathrm{mL}$.

4. Aged 18-65 years old.

Exclusion criteria:

1. Patients with other viral hepatitis (hepatitis A, C, D, and E) or other liver diseases (such as autoimmune liver disease, Wilson's disease, alcoholic liver disease, or drug hepatitis).

2. Decompensated cirrhosis or liver cancer.

3. HIV infection, lesions of important organs (such as lesions of the heart, brain, lung, kidney, or fundus), severe metabolic diseases, malignant tumors, severe mental diseases, etc.

4. Hyperthyroidism or hypothyroidism, combined with other autoimmune diseases.

5. Patients with interferon allergy, alcoholism, or drug addiction.

6. Patients receiving chemotherapy or immunosuppressive therapy.

\section{Treatment Plan}

In this non-randomized study, patients in the control group received continued NAs monotherapy. Patients in the PegIFN $\alpha-2 b$ addon treatment group received combination therapy of PegIFN $\alpha-2 b$ ( $180 \mu \mathrm{g} /$ week, subcutaneous injection) and NAs [entecavir (ETV), tenofovir (TDF), or tenofovir alafenamide (TAF)]. If patients took lamivudine (LAM), telbivudine (LdT), or adefovir (ADV) previously, they took ETV instead. If patients took ETV, TDF, or TAF previously, they continued previous NAs therapy.

All patients received PegIFN $\alpha-2 b+N A$ or NA for at least 48 weeks. After finishing 48 weeks of treatment, patients chose to continue peginterferon therapy up to 72 weeks or discontinue peginterferon therapy voluntarily. If patients obtained HBsAg clearance at week 48, NA was stopped; otherwise, NA was continued.

\section{Data Collection}

1. Baseline information: gender, age, history of alcohol consumption, family history of hepatitis B, history of antiviral therapy, and history of interferon therapy.

2. Laboratory test: white blood cell (WBC), peripheral blood neutrophil (NEUT), platelet (PLT), hemoglobin ( $\mathrm{Hb})$, total bilirubin (TBIL), alanine aminotransferase (ALT), aspartate aminotransferase (AST), HBV DNA quantification, $\mathrm{HBsAg}$ and $\mathrm{HBeAg}$ at baseline and at week 12, 24, 48, 72 during treatment.

3. Thyroid function, autoantibodies, alpha-fetoprotein (AFP), and abdominal ultrasound at baseline and during treatment.

The quantitative detection of HBV DNA was measured by high-sensitivity fluorescence quantitative real-time PCR with lower detection limit of $10 \mathrm{IU} / \mathrm{mL}$. The quantitative detection of HBV markers (HBsAg, HBsAb, and HBeAg) were measured by Abbott Chemilescent Automatic Immunoanalyzer (ARCHTIECT i2000sr). The lower limit of HBsAg detection was $0.05 \mathrm{IU} / \mathrm{mL}$, and $\mathrm{HBsAb}$ level $>10 \mathrm{IU} / \mathrm{mL}$ was defined as positive.

\section{Evaluation of Therapeutic Efficacy}

The primary endpoint was HBsAg clearance at week 48. The secondary endpoint was HBsAg serological conversion rate and HBV DNA levels at week 48, HBsAg clearance, and HBsAg serological conversion at week 12, 24 and 72 . Complete response was defined as 
HBsAg $<0.05 \mathrm{IU} / \mathrm{mL}$ and non-complete response was defined as $\mathrm{HBsAg} \geq 0.05 \mathrm{IU} / \mathrm{mL}$.

\section{Statistical Analysis}

Data analysis of primary and secondary endpoints in this study was performed in the perprotocol (PP) population. Response rates were summarized by calculating percentage at week 48 and week 72. Data analysis for safety was performed in the safety population. Measurement data with normal distribution were expressed as mean \pm standard deviation (SD). Measurement data with non-normal distribution were expressed by median [25th, 75th] $(\mathrm{M}[\mathrm{P} 25, \mathrm{P} 75])$. Counting data were expressed in frequency (\%). $T$ test or non-parametric test was used for comparison of continuous variables between groups. Categorical variables were compared by chi-square test or Fisher exact test. All data were analyzed by SPSS 20.0 and graphpad prism 7.0. $P<0.05$ was statistically significant.

\section{RESULTS}

\section{Patients and General Information}

A total of 196 NAs-treated patients with $\mathrm{CHB}$ met the inclusion criteria, including three patients with loss to follow-up in the PegIFNa$2 \mathrm{~b}$ add-on group (one because of hyperthyroidism, one because of continuous aminotransferase elevation, and one because of severe flu-like symptoms during the treatment), and 10 lost to follow-up in the NAs monotherapy group (Fig. 1). Therefore, 183 NAs-treated patients with CHB (108 in the PegIFN $\alpha$-2b addon group and 75 in the NAs monotherapy group) were enrolled in the study eventually. Baseline characteristics of gender, HBsAg level, HBV DNA, WBC, NEUT, Hb, TBIL, ALT, and AST were not statistically different between the two groups, whereas age and PLT level were (Table 1).

\section{Virological Response}

Ten patients were HBV DNA positive at baseline and all turned HBV DNA negative (HBV DNA $<10$ IU $/ \mathrm{mL}$ ) after 48 weeks of PegIFN $\alpha-2 b$ treatment. At the end of 48 weeks of treatment, $100 \%(108 / 108)$ and $97.33 \%(73 / 75)$ patients maintained HBV DNA suppression in the PegIFN $\alpha$-2b add-on group and NAs monotherapy group, respectively. Three patients $(4.0 \%$, $3 / 75$ ) had increased HBV DNA at week 48 by NAs monotherapy, but no significant difference compared with PegIFN $\alpha-2 b$ add-on therapy $(P=0.067)$ (Table 2).

\section{Serological Response}

At week 48, HBsAg clearance (50.93\%, 55/108) and HBsAg seroconversion (48.15\%, 52/108) were achieved only in patients with PegIFN $\alpha-2 b$ add-on therapy. Significantly more patients with PegIFN $\alpha$-2b add-on therapy had low HBsAg level $(0.05 \leq \mathrm{HBsAg}<10 \mathrm{IU} / \mathrm{mL})$ than those with NAs monotherapy $(23.15 \%$ vs $4.0 \%$, $P=0.000$ ) (Table 3). In addition, HBsAg level showed a downward trend during PegIFN $\alpha-2 b$ treatment. The percentage of patients with HBsAg $<0.05 \mathrm{IU} / \mathrm{mL}$ increased gradually, while those with $\mathrm{HBsAg}>10 \mathrm{IU} / \mathrm{mL}$ decreased gradually during PegIFN $\alpha$-2b add-on therapy (Fig. 2).

For 108 patients with PegIFN $\alpha-2 b$ add-on therapy, HBsAg clearance and HBsAg seroconversion were increased over 48 weeks of treatment (Table 4). Patients with baseline HBsAg level $<100 \mathrm{IU} / \mathrm{mL}$ and HBsAg level 100-500 IU/ $\mathrm{mL}$ achieved significantly higher HBsAg clearance than those with baseline HBsAg level $500-1500$ at week 12,24 , and $48(P=0.001$ vs $P=0.000$ vs $P=0.042$ respectively). Similarly, baseline HBsAg level $500-1500 \mathrm{IU} / \mathrm{mL}$ was associated with the lowest HBsAg seroconversion. In addition, at week 48 , the HBsAg seroconversion was significantly different among patients with HBsAg level $<100 \mathrm{IU} / \mathrm{mL}$, $100-500 \mathrm{IU} / \mathrm{mL}$, and $500-1500 \mathrm{IU} / \mathrm{mL}(58.70 \%$ vs $54.84 \%$ vs $25.81 \%, P=0.012$ ) (Table 4 ).

There were 95 patients with available data at week 72, including $47 \mathrm{HBsAg}$-positive patients and 48 HBsAg-negative patients at week 48 . 


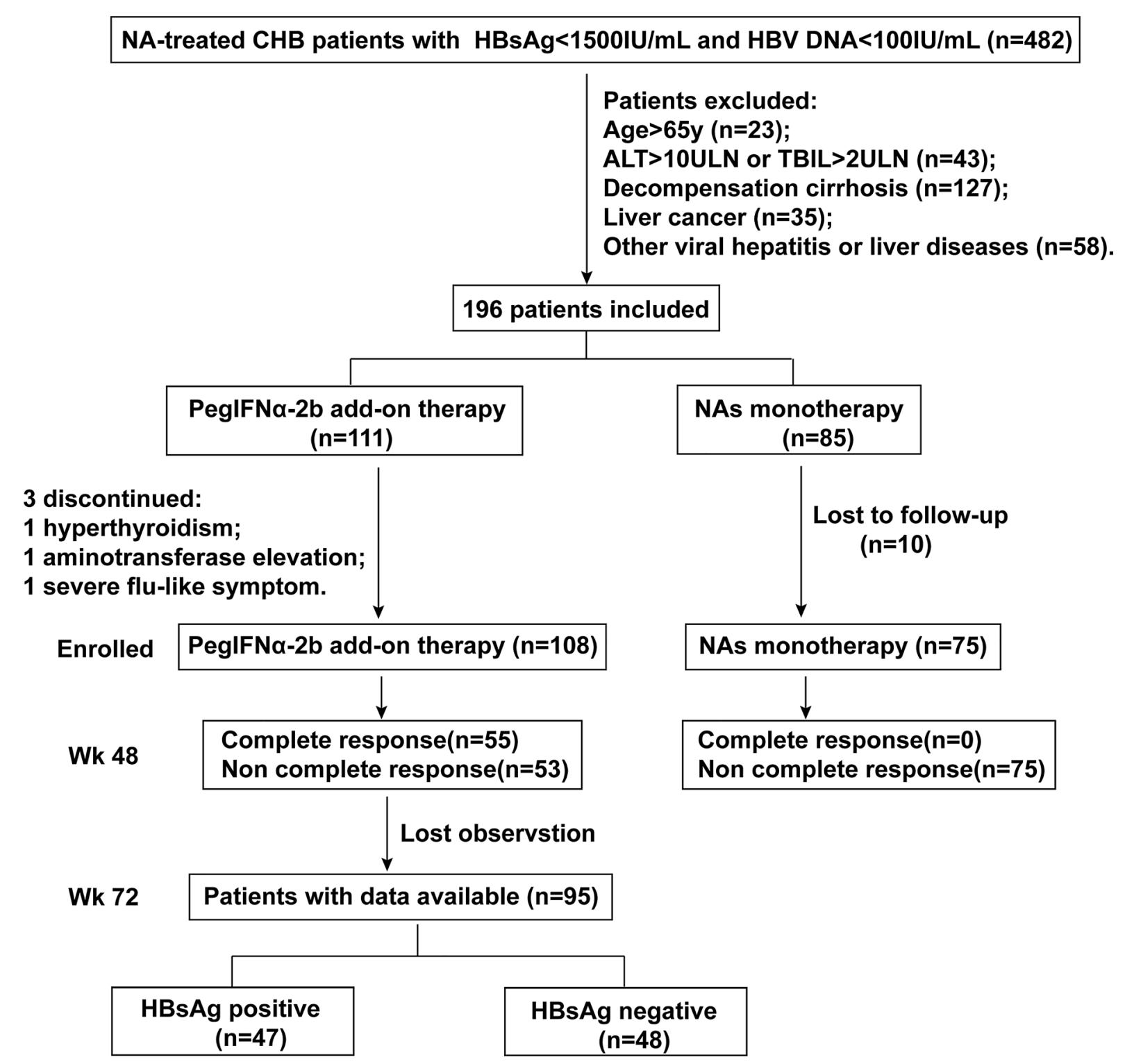

Fig. 1 Flow chart of interferon therapy of 183 NAs-treated patients with CHB

Both HBsAg clearance and HBsAg seroconversion were not significantly different between continued (18 patients) and discontinued (29 patients) PegIFN $\alpha$-2b therapy at week 72 in 47 HBsAg-positive patients $(16.67 \%$ vs $13.79 \%$, $P=0.582$ and $33.33 \%$ vs $20.69 \%, P=0.493$ respectively). In addition, $83.33 \%(5 / 6)$ and 95.24\% (40/42) achieved HBsAg seroconversion for continued or discontinued PegIFN $\alpha-2 b$ therapy respectively at week 72 in $48 \mathrm{HBsAg}$ negative patients $(P=0.336)$ (Table 5$)$.

Safety

During the 48 weeks of treatment, more patients in PegIFN $\alpha$-2b add-on therapy group experienced adverse events, such as transient influenza-like symptoms in the early stage (fever, fatigue, and muscle soreness), 
Table 1 Baseline characteristics of 183 patients with CHB treated with NAs or PegIFN $\alpha-2 b$ combination therapy

\begin{tabular}{|c|c|c|c|}
\hline & PegIFN $\alpha-2 b+$ NAs $(N=108)$ & NAs $(N=75)$ & $P$ value \\
\hline Age (years) & $40.04 \pm 8.42$ & $45.15 \pm 10.54$ & 0.001 \\
\hline Male, $n(\%)$ & $95(87.96 \%)$ & $61(81.33 \%)$ & 0.214 \\
\hline Previous NA treatment, $n(\%)$ & & & - \\
\hline ETV & $79(73.15 \%)$ & $62(82.67 \%)$ & \\
\hline TDF & $17(15.74 \%)$ & $13(17.33 \%)$ & \\
\hline Others (LAM, ADV, OR LdT) & $12(11.11 \%)$ & 0 & \\
\hline HBsAg level (IU/mL) & & & 0.272 \\
\hline$<500$ & $77(71.30 \%)$ & $45(60.00 \%)$ & \\
\hline $500-1000$ & $24(22.22 \%)$ & $24(32.00 \%)$ & \\
\hline $1000-1500$ & $7(6.48 \%)$ & $6(8.00 \%)$ & \\
\hline HBV-DNA, $n(\%)$ & & & 0.767 \\
\hline Undetectable $(<10 \mathrm{IU} / \mathrm{mL})$ & $98(90.74 \%)$ & $69(92.00 \%)$ & \\
\hline $10-100 \mathrm{IU} / \mathrm{mL}$ & $10(9.26 \%)$ & $6(8.00 \%)$ & \\
\hline WBC $\left(10^{9} / \mathrm{L}\right)$ & $6.05 \pm 1.31$ & $6.08 \pm 1.89$ & 0.905 \\
\hline $\operatorname{NEUT}\left(10^{9} / \mathrm{L}\right)$ & $3.51 \pm 1.00$ & $3.53 \pm 1.49$ & 0.943 \\
\hline $\mathrm{Hb}(\mathrm{g} / \mathrm{L})$ & $160(149,167)$ & $158(146,162)$ & 0.075 \\
\hline $\operatorname{PLT}\left(10^{9} / \mathrm{L}\right)$ & $205.21 \pm 52.59$ & $174.71 \pm 61.88$ & 0.001 \\
\hline $\mathrm{TBIL}(\mu \mathrm{mol} / \mathrm{L})$ & $11.55(9.20,16.80)$ & $12.10(9.90,17.03)$ & 0.283 \\
\hline $\operatorname{ALT}(\mathrm{U} / \mathrm{L})$ & $25.00(20.73,37.65)$ & $25.00(19.10,34.86)$ & 0.430 \\
\hline $\operatorname{AST}(\mathrm{U} / \mathrm{L})$ & $25.25(22.30,29.93)$ & $26.25(22.48,31.58)$ & 0.392 \\
\hline
\end{tabular}

ETV entecavir, TDF tenofovir, $L A M$ lamivudine, $A D V$ adefovir, $L d T$ telbivudine, $W B C$ white blood cell, NEUT neutrophil, $H b$ hemoglobin, $P L T$ platelet, $T B I L$ total bilirubin, $A L T$ alanine aminotransferase, $A S T$ aspartate aminotransferase

neutropenia $\left(\mathrm{NEUT}<1.50 \times 10^{9} / \mathrm{L}\right)$, thrombocytopenia (PLT $\left.<100 \times 10^{9} / \mathrm{L}\right)$, and elevated ALT or AST (Table 6). Three patients discontinued the treatment and were removed from the PegIFN $\alpha$-2b add-on therapy group (one because of hyperthyroidism, one because of continuous elevation of transaminase, and one because of severe flu-like symptoms). One out of 111 PegIFN $\alpha-2 b$ recipients developed ALT flare (ALT $>5$ upper limit of normal). No NAs recipients discontinued treatment for safety reasons or experienced ALT flare. All side events were alleviated by timely treatment.

\section{DISCUSSION}

Most patients with $\mathrm{CHB}$ failed to withdraw the drug after achieving HBeAg clearance and HBV DNA inhibition by NAs therapy, because HBsAg clearance rate was extremely low by NAs monotherapy. PegIFN-based sequential/combination therapy is important to achieve optimal clinical cure. Previous study showed that 52.2\% of $\mathrm{HBeAg}$-negative patients with $\mathrm{CHB}$ with HBsAg $<10 \mathrm{IU} / \mathrm{mL}$ achieved clinical cure by PegIFN-based therapy [23]. This study focused on HBeAg-negative patients with CHB with low 
Table 2 Virological response at 48 weeks of treatment

\begin{tabular}{llll}
\hline HBV DNA $(\boldsymbol{n}, \boldsymbol{\%})$ & PegIFN $\boldsymbol{\alpha}-\mathbf{2 b}+\mathbf{N A s}(\boldsymbol{N}=\mathbf{1 0 8})$ & $\mathbf{N A s}(\boldsymbol{N}=\mathbf{7 5})$ & $\boldsymbol{P}$ value \\
\hline Undetectable $(<10 \mathrm{IU} / \mathrm{mL})$ & $108,100.0 \%$ & $72,96.0 \%$ & 0.067 \\
HBV DNA suppression $(<100 \mathrm{IU} / \mathrm{mL})$ & $108,100.0 \%$ & $73,97.33 \%$ & 0.167 \\
HBV DNA increased & $0,0.0 \%$ & $3,4.0 \%$ & 0.067 \\
\hline
\end{tabular}

Table 3 Serological response at 48 weeks of treatment

\begin{tabular}{llll}
\hline Serological response $(\boldsymbol{n}, \boldsymbol{\%})$ & PegIFN $\boldsymbol{\alpha}-\mathbf{2 b}+\mathbf{N A s}(\boldsymbol{N}=\mathbf{1 0 8})$ & NAs $(\boldsymbol{N}=\mathbf{7 5})$ & $\boldsymbol{P}$ value \\
\hline HBsAg clearance $(<0.05 \mathrm{IU} / \mathrm{mL})$ & $55,50.93 \%$ & $0,0.0 \%$ & 0.000 \\
$0.05 \leq \mathrm{HBsAg}<10 \mathrm{IU} / \mathrm{mL}$ & $25,23.15 \%$ & $3,4.0 \%$ & 0.000 \\
HBsAg seroconversion & $52,48.19 \%$ & $0,0.0 \%$ & 0.000 \\
\hline
\end{tabular}

HBsAg level $(<1500 \mathrm{IU} / \mathrm{mL})$ and low viral load (HBV DNA $<100 \mathrm{IU} / \mathrm{mL}$ ) after NAs treatment, aiming to evaluate the efficacy and safety of PegIFN $\alpha$ - $2 b$ add-on therapy.

NAs and PegIFN can achieve virologic responses through different mechanisms [24-26]. After 48 weeks of add-on treatment of PegIFN $\alpha-2 b, H B V$ DNA was undetectable in all patients. To our acknowledge, NAs are very

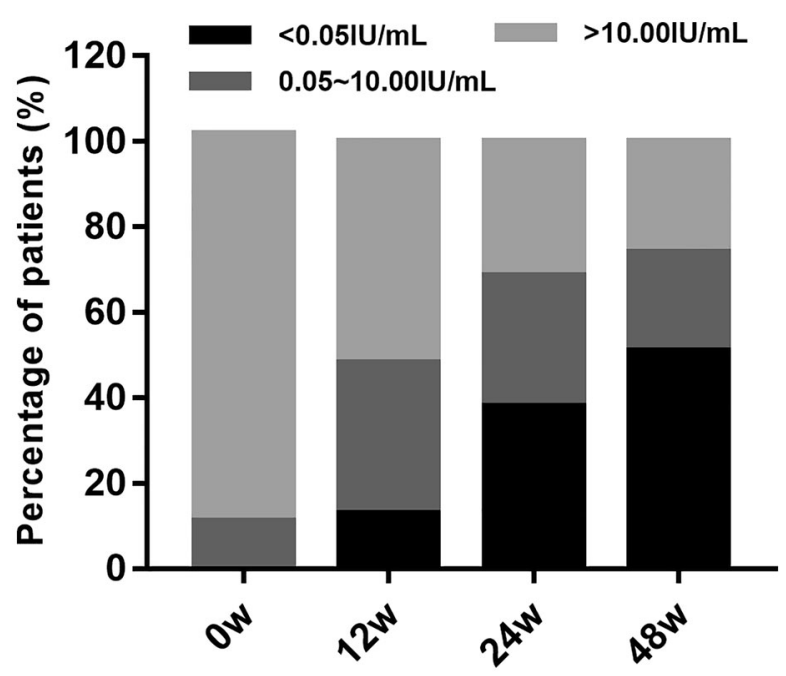

Fig. 2 Different HBsAg levels during treatment. HBsAg level showed a downward trend during PegIFN $\alpha-2 b$ treatment effective in suppressing HBV DNA in patients with CHB. Previous studies showed that the virologic response of PegIFN and NAs combination therapy was as good as that of NAs monotherapy [27, 28]. Our study also showed that PegIFN $\alpha$-2b add-on therapy was effective at maintaining viral suppression. No patients experienced viral rebound or HBV DNA increase during PegIFN $\alpha$-2b add-on therapy.

HBsAg clearance represents clinical cure for HBeAg-negative patients with CHB. The OSST trial showed 22.2\% HBsAg clearance among PegIFN alfa-2a-treated patients with HBeAg loss and HBsAg $<1500 \mathrm{IU} / \mathrm{ml}$ [19]. Yan et al. [25] showed 15\% HBsAg clearance at week 48 among PegIFN add-on therapy patients with negative HBeAg. Wu et al. [20] showed 37.4\% HBsAg clearance and $29.7 \%$ HBsAg seroconversion in PegIFN $\alpha-2 \mathrm{a}$ add-on therapy patients with HBsAg $<1500 \mathrm{IU} / \mathrm{mL}$. Compared with those published studies [19, 20, 25], our study showed higher rates of HBsAg clearance (50.93\%) and HBsAg seroconversion (48.15\%) at week 48 following PegIFN $\alpha-2 b$ add-on therapy. This better outcome might be attributed to the lower HBV DNA and HBsAg level at baseline in our study, since low HBsAg and HBV DNA levels were closely related to response to PegIFN add-on therapy and high HBsAg clearance rate [26, 28]. On the other hand, Chan et al. [29] reported 


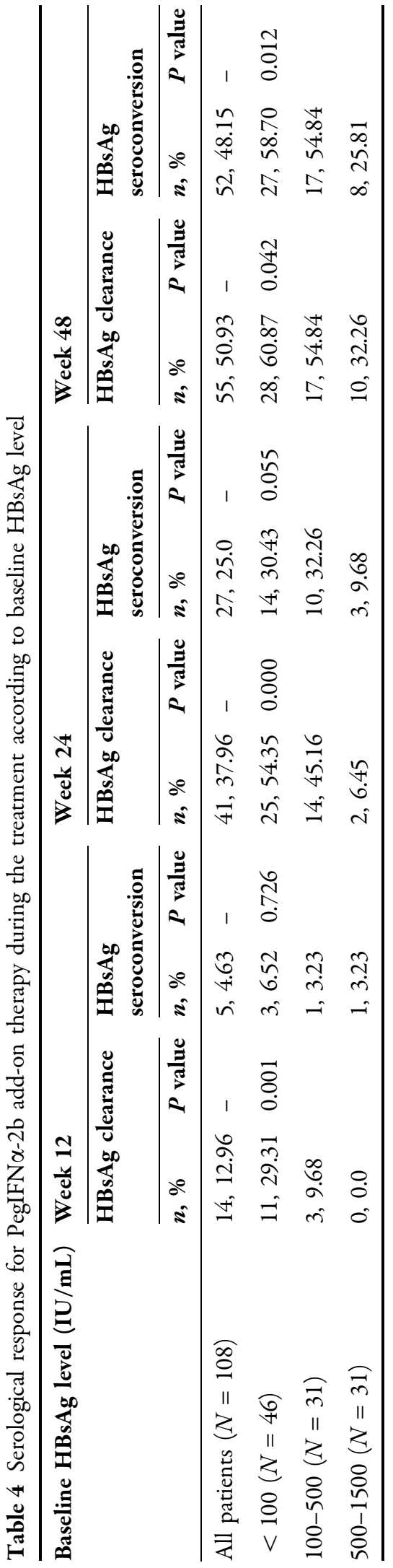

that $50 \%$ of $\mathrm{HBeAg}$-positive patients with $\mathrm{CHB}$ with baseline $\mathrm{HBsAg}<500 \mathrm{IU} / \mathrm{mL}$ achieved HBsAg loss after 48 weeks of PegIFN treatment. In our study, we also showed that HBeAg-negative patients with $\mathrm{CHB}$ with low HBsAg $(<1500 \mathrm{IU} / \mathrm{mL})$ and low HBV DNA $(<100 \mathrm{IU} /$ $\mathrm{mL}$ ) levels at enrollment had a good chance of achieving HBsAg clearance. In addition, we found that patients with $\mathrm{HBsAg}<100 \mathrm{IU} / \mathrm{mL}$ had the highest rate of HBsAg clearance (up to $60.87 \%$ at week 48 ). Therefore, it would be valuable for clinical practice to identify them as the best candidates for PegIFN add-on therapy.

More interestingly, our results indicated that longer-term PegIFN $\alpha$-2b add-on therapy could not improve HBsAg clearance or HBsAg seroconversion after 48 weeks of PegIFN $\alpha$ - $2 b$ add-on therapy. For HBeAg-negative or HBeAg-positive patients at week 48, HBsAg clearance and HBsAg seroconversion had no significant difference by continuing or discontinuing PegIFN $\alpha-2 b$ therapy at week 72. Previous study showed that HBsAg clearance and seroconversion did not increase at week 72 compared with that at week 48 [25]. Hu et al. [21] also showed that the differences of HBsAg clearance were not statistically significant between week 48 and week 96, although HBsAg loss rates were improved from $14.4 \%$ to $20.7 \%$ by extending treatment from 48 to 96 weeks. Therefore, it would be unnecessary to prolong PegIFN $\alpha-2 b$ treatment duration in clinical practice.

Generally, PegIFN $\alpha-2 b$ add-on therapy was safe and well tolerated for NAs-treated patients with CHB. Most patients had transient flu-like symptoms, transaminase elevation $(2-5 \times \mathrm{ULN})$, and mild to moderate neutropenia, but could be mitigated by symptomatic treatment. Therefore, it is critical to regularly review and quickly treat adverse events during PegIFN $\alpha-2 b$ application.

In summary, we analyzed the effect of PegIFN $\alpha-2 b$ in HBeAg-negative patients with CHB with low HBsAg level through an observation study. We found that PegIFN $\alpha-2 b$ could effectively inhibit HBV replication, reduce HBV antigen generation, and improve seroconversion. HBeAg-negative patients with $\mathrm{CHB}$ with low HBsAg level could achieve clinical cure and had drug withdrawal safely by PegIFN $\alpha$-2b add- 
Table 5 Serological response for PegIFN $\alpha$-2b add-on therapy at week 72 according to week 48 HBsAg status

\begin{tabular}{|c|c|c|c|c|c|}
\hline \multirow[t]{2}{*}{ Week 48 HBsAg status } & \multirow[t]{2}{*}{ PegIFN $\alpha-2 b$ therapy } & \multicolumn{2}{|c|}{ Week 72 HBsAg clearance } & \multicolumn{2}{|c|}{ Week 72 HBsAg seroconversion } \\
\hline & & $n / N(\%)$ & $P$ value & $n / N(\%)$ & $P$ value \\
\hline \multirow[t]{2}{*}{ HBsAg positive $\left(N_{0}=47\right)$} & Continuous & $3 / 18(16.67)$ & 0.582 & $6 / 18(33.33)$ & 0.493 \\
\hline & Discontinued & $4 / 29(13.79)$ & & $6 / 29(20.69)$ & \\
\hline \multirow[t]{2}{*}{ HBsAg negative $\left(N_{0}=48\right)$} & Continuous & - & - & $5 / 6(83.33)$ & 0.336 \\
\hline & Discontinued & - & & $40 / 42(95.24)$ & \\
\hline
\end{tabular}

on therapy. Baseline HBsAg $<100 \mathrm{IU} / \mathrm{mL}$ predicted a better chance of HBsAg clearance. In addition, it would be unnecessary to prolong PegIFN $\alpha$-2b treatment duration after 48 weeks of PegIFN $\alpha$-2b add-on therapy. However, further study should be carried out to verify the results in the future.

This study has certain limitations: (1) This is a single-center real-world study, and the sample size of HBeAg-negative CHB population is not large; (2) The current study is still under way. Some patients had limited follow-up time,

Table 6 Safety outcome of the study population

\begin{tabular}{|c|c|c|}
\hline Adverse events, $n(\%)$ & $\begin{array}{l}\text { PegIFN } \alpha- \\
2 b+\text { NAs } \\
(N=111)\end{array}$ & $\begin{array}{l}\text { NAs } \\
(N=75)\end{array}$ \\
\hline Influenza-like illness & $87(78.38)$ & $0(0.0)$ \\
\hline Neutropenia & $81(72.97)$ & $3(4.0)$ \\
\hline Thrombocytopenia & $56(50.45)$ & $\begin{array}{l}11 \\
\quad(14.67)\end{array}$ \\
\hline ALT increased & $81(72.97)$ & $8(10.67)$ \\
\hline AST increased & $86(77.48)$ & $\begin{array}{l}13 \\
(17.33)\end{array}$ \\
\hline $\begin{array}{l}\text { Discontinuation for } \\
\text { safety reasons }\end{array}$ & $3(2.7)$ & $0(0.0)$ \\
\hline Death & $0(0.0)$ & $0(0.0)$ \\
\hline ALT flare $(>5 \mathrm{ULN})$ & $1(0.9)$ & $0(0.0)$ \\
\hline
\end{tabular}

which did not involve the long-term response of HBsAg clearance after drug withdrawal. (3) Baseline age and PLT level between PegIFN $\alpha$ $2 b+$ NAs therapy and NAs monotherapy were statistically different. (4) The treatment response of PegIFN $\alpha-2 b$ is affected by $\mathrm{HBV}$ genotype. However, as a result of the continuous HBV DNA suppression $(<100 \mathrm{IU} / \mathrm{mL})$ in the enrolled $\mathrm{CHB}$ population, the impact of $\mathrm{HBV}$ genotype on response was not explored.

\section{CONCLUSIONS}

HBeAg-negative patients with $\mathrm{CHB}$ with low HBsAg level could achieve high HBsAg clearance and seroconversion by PegIFN $\alpha-2 b$ add-on therapy. Patients with low baseline HBsAg levels were more likely to obtain HBsAg clearance. PegIFN $\alpha$-2b add-on therapy could be a good treatment option for NAs-treated patients with $\mathrm{CHB}$ with negative $\mathrm{HBeAg}$, particularly for those with lower HBsAg level $(<100 \mathrm{IU} / \mathrm{mL})$. This will have important implications for PegIFN $\alpha-2 b$ treatment screening in HBeAg-negative patients with $\mathrm{CHB}$. It would be unnecessary to prolong PegIFN $\alpha-2 b$ treatment duration after fininshing 48 weeks PegIFN $\alpha$ - $2 b$ treatment in clinical practice.

\section{ACKNOWLEDGEMENTS}

We thank the participants of the study.

Funding. This work was supported by the National Key R\&D Program of China (No. 
2017YFC0908104); the National Science and Technology Major Project of China (No. 2018ZX10732-202-001-007); the National Natural Science Foundation of China (No. 81970550); the National Natural Science Foundation of China (No. 81970523); the Natural Science Foundation of Hunan Province (2020JJ4877); the National Science and Technology Major Project (2018ZX10723203); the Natural Science Foundation of Hunan Province, China (2019JJ40496); the National Natural Science Foundation of Hunan province (No. 2019JJ30041); the National Natural Science Foundation of China (No. 82070613), and Innovation-Driven Project of Central South University (No. 2020CX044). The Rapid Service Fee was funded by the authors.

Authorship. All named authors meet the International Committee of Medical Journal Editors (ICMJE) criteria for authorship for this article, take responsibility for the integrity of the work as a whole, and have given their approval for this version to be published.

Authorship Contributions. Ze-Bing Huang and Yan Huang designed the study. Min Qi collected the data. Jun Chen analyzed the data and drafted the manuscript. Ruo-Chan Chen, Xing-Wang $\mathrm{Hu}$, and Xue-Gong Fan modified the manuscript. Cheng-Jin Liao, Li-Yuan Long, Xiao-Ting Zhao, Min Tan, and Hai-Fu Li checked the data. All authors contributed to the revision of the manuscript and approved the final manuscript.

Disclosures. All authors declare that they have no conflict of interest in this research.

Compliance with Ethics Guidelines. All enrolled patients chose to receive PegIFN $\alpha-2 b$ treatment voluntarily with full knowledge and signed an informed consent. This study was in compliance with the Declaration of Helsinki and was approved by Xiangya Hospital Ethics Committee, Central South University.

Data Availability. The datasets generated during and/or analyzed during the current study are available from the corresponding author on reasonable request.

Open Access. This article is licensed under a Creative Commons Attribution-NonCommercial 4.0 International License, which permits any non-commercial use, sharing, adaptation, distribution and reproduction in any medium or format, as long as you give appropriate credit to the original author(s) and the source, provide a link to the Creative Commons licence, and indicate if changes were made. The images or other third party material in this article are included in the article's Creative Commons licence, unless indicated otherwise in a credit line to the material. If material is not included in the article's Creative Commons licence and your intended use is not permitted by statutory regulation or exceeds the permitted use, you will need to obtain permission directly from the copyright holder. To view a copy of this licence, visit http://creativecommons.org/licenses/by$\mathrm{nc} / 4.0 /$.

\section{REFERENCES}

1. Yuen MF, Chen DS, Dusheiko GM, et al. Hepatitis B virus infection. Nat Rev Dis Primers. 2018;4:18035.

2. Chang MH. Natural history and clinical management of chronic hepatitis B virus infection in children. Hepatol Int. 2008;2:28-36.

3. Kao JH, Chen DS. Global control of hepatitis B virus infection. Lancet Infect Dis. 2002;2:395-403.

4. McMahon BJ. The natural history of chronic hepatitis B virus infection. Hepatology. 2009;49:S4555.

5. Zhou KL, Contag C, Whitaker E, Terrault N. Spontaneous loss of surface antigen among adults living with chronic hepatitis B virus infection: a systematic review and pooled meta-analyses. Lancet Gastroenterol Hepatol. 2019;4:227-38.

6. Liem KS, Fung S, Wong DK, et al. Limited sustained response after stopping nucleos(t)ide analogues in patients with chronic hepatitis B: results from a randomised controlled trial (Toronto STOP study). Gut. 2019;68:2206-13. 
7. Sarin SK, Kumar M, Lau GK, et al. Asian-Pacific clinical practice guidelines on the management of hepatitis B: a 2015 update. Hepatol Int. 2016;10: 1-98.

8. Boglione L, D'Avolio A, Cariti G, et al. Kinetics and prediction of HBsAg loss during therapy with analogues in patients affected by chronic hepatitis B HBeAg negative and genotype D. Liver Int. 2013;33: 580-5.

9. Chevaliez S, Hezode C, Bahrami S, Grare M, Pawlotsky JM. Long-term hepatitis B surface antigen (HBsAg) kinetics during nucleoside/nucleotide analogue therapy: finite treatment duration unlikely. J Hepatol. 2013;58:676-83.

10. Seto WK, Hui AJ, Wong VW, et al. Treatment cessation of entecavir in Asian patients with hepatitis B e antigen negative chronic hepatitis B: a multicentre prospective study. Gut. 2015;64: $667-72$.

11. Liu F, Wang L, Li XY, et al. Poor durability of lamivudine effectiveness despite stringent cessation criteria: a prospective clinical study in hepatitis B e antigen-negative chronic hepatitis B patients. J Gastroenterol Hepatol. 2011;26:456-60.

12. Chaung KT, Ha NB, Trinh HN, et al. High frequency of recurrent viremia after hepatitis B e antigen seroconversion and consolidation therapy. J Clin Gastroenterol. 2012;46:865-70.

13. Dai CY, Tseng TC, Wong GL, et al. Consolidation therapy for HBeAg-positive Asian chronic hepatitis B patients receiving lamivudine treatment: a multicentre study. J Antimicrob Chemother. 2013;68:2332-8.

14. Lee HW, Lee HJ, Hwang JS, et al. Lamivudine maintenance beyond one year after $\mathrm{HBeAg}$ seroconversion is a major factor for sustained virologic response in $\mathrm{HBeAg}$-positive chronic hepatitis $\mathrm{B}$. Hepatology. 2010;51:415-21.

15. Jeng WJ, Chen YC, Chien RN, Sheen IS, Liaw YF. Incidence and predictors of hepatitis B surface antigen seroclearance after cessation of nucleos(t)ide analogue therapy in hepatitis B e antigennegative chronic hepatitis B. Hepatology. 2018;68: 425-34.

16. Lee HW, Lee JI, Kim S, Kim S, Chang HY, Lee KS. Cumulative incidence of hepatocellular carcinoma and hepatitis B surface antigen seroclearance after nucleos $(\mathrm{t})$ ide analogue-induced hepatitis $\mathrm{B}$ e antigen seroclearance. BMC Gastroenterol 2020;20(1): 113.

17. Boglione L, Cariti G, Di Perri G, D'Avolio A. Sequential therapy with entecavir and pegylated interferon in a cohort of young patients affected by chronic hepatitis B. J Med Virol. 2016;88:1953-9.

18. Wursthorn K, Lutgehetmann M, Dandri M, et al. Peginterferon alpha-2b plus adefovir induce strong cccDNA decline and HBsAg reduction in patients with chronic hepatitis B. Hepatology. 2006;44: 675-84.

19. Ning Q, Han M, Sun $Y$, et al. Switching from entecavir to PegIFN alfa-2a in patients with HBeAgpositive chronic hepatitis B: a randomised openlabel trial (OSST trial). J Hepatol. 2014;61:777-84.

20. Wu FP, Yang Y, Li M, et al. Add-on pegylated interferon augments hepatitis B surface antigen clearance vs continuous nucleos(t)ide analog monotherapy in Chinese patients with chronic hepatitis B and hepatitis B surface antigen $</=1500$ IU/mL: an observational study. World J Gastroenterol. 2020;26:1525-39.

21. Hu P, Shang J, Zhang W, et al. HBsAg loss with Peginterferon alfa-2a in hepatitis B patients with partial response to nucleos(t)ide analog: new switch study. J Clin Transl Hepatol. 2018;6:25-34.

22. Chinese Association of Infectious Diseases, Chinese Association of Liver Diseases. The guidelines for the prevention and treatment of chronic hepatitis B (2019 edition). Chin Hepatol. 2019;24(12): $1335-1355$

23. Brunetto MR, Moriconi F, Bonino F, et al. Hepatitis B virus surface antigen levels: a guide to sustained response to peginterferon alfa- $2 \mathrm{a}$ in $\mathrm{HBeAg}$ negative chronic hepatitis B. Hepatology. 2009;49: 1141-50.

24. Thimme R, Dandri M. Dissecting the divergent effects of interferon-alpha on immune cells: time to rethink combination therapy in chronic hepatitis B? J Hepatol. 2013;58:205-9.

25. Yan L, Zhu C, Li J, et al. Entecavir add-on or switchto pegylated interferon improves HBsAg clearance in $\mathrm{HBe}$ antigen negative chronic hepatitis B patients. Infect Drug Resist. 2018;11:2001-2009.

26. Tseng TC, Kao JH. Clinical utility of quantitative HBsAg in natural history and nucleos(t)ide analogue treatment of chronic hepatitis B: new trick of old dog. J Gastroenterol. 2013;48:13-21.

27. Cao ZH, Liu YL, Ma LN, et al. A potent hepatitis B surface antigen response in subjects with inactive hepatitis B surface antigen carrier treated with pegylated-interferon alpha. Hepatology. 2017;66: 1058-66.

28. Liem KS, van Campenhout MJH, Xie Q, et al. Low hepatitis B surface antigen and HBV DNA levels 
predict response to the addition of pegylated interferon to entecavir in hepatitis B e antigen positive chronic hepatitis B. Aliment Pharmacol Ther. 2019;49:448-56.

29. Chan HLY, Chan FWS, Hui AJ, et al. Switching to peginterferon for chronic hepatitis B patients with hepatitis B e antigen seroconversion on entecavira prospective study. J Viral Hepatitis. 2019;26: 126-35.

\section{Publisher's Note}

Springer Nature remains neutral with regard to jurisdictional claims in published maps and institutional affiliations. 